\title{
THE IMPORTANCE OF THIS AND THAT: REFLECTIONS ON CONTEXT IN EARLY ISLAMIC PHILOSOPHY
}

\section{Phil Enns}

Toronto University, Canada

\begin{abstract}
The discussion over the relationship between what is true globally and what is true locally is not new. It might be helpful, therefore, to consider issues surrounding the relationship between globalization and local values in light of previous forms of this discussion. To this end, I would like to reflect on the discussion of context in the writings of al-Farabi, Ibn Sina and al-Ghazăli. To focus this paper, I will consider only three issues, namely that of history, science and the role of reason in religion. I will argue that al-Farabi and Ibn Sina present an account of context that begins with experience as a foundation and then moves to the universal, emphasizing the importance of tradition, demonstration and rationality. Against these two, al-Ghazāi argues for the importance of leaving bebind experience in order to reach that which is certain, emphasizing the supernatural, intuition and mystical. My goal is to draw out some implications these writers recognized followed from their often dense and esoteric discussions of the nature of particulars and universals, and conclude with some suggestions for our contemporary situation.
\end{abstract}

Keywords: Knowledge, al-Ghazāili, al-Farabi, Ibn Sina

\section{A. Introduction}

The disagreement between al-Farabi and Ibn Sina on one side, and al-Ghazāili on the other can be understood as primarily a disagreement 
about whether context is important for knowledge. Al-Farabi describes the natural development of knowledge, starting from particulars and developing into language, that only reaches certainty with theoretical and practical philosophy. For al-Farabi, it is only the philosopher who has true knowledge because it is only the philosopher who sees the universal qualities lying within particular things. Ibn Sina provides a similar, though more metaphysical, account of the development of knowledge. Knowledge begins with sense perception of particulars from which the rational soul abstracts universals. For Ibn Sina, then, it is only the philosopher who has true knowledge because it is only the philosopher who can establish the proper relationship between the practical intellect and the theoretical intellect. Both al-Farabi and Ibn Sina agree that context is essential for knowledge in that knowledge must begin with experiences of particular and individual things, and from this foundation develop a philosophical understanding that uncovers the universals which lie hidden within these particulars.

Against al-Farabì and Ibn Sina, al-Ghazā̄i argues that this philosophy, with its reliance on experience of particulars and a method of demonstration, cannot provide the certainty that philosophers claim it does. Methodically working through the limitations of sense perception and empirical demonstration, al-GhazāTi concludes that certainty cannot be had within any particular context, and so knowledge must therefore necessarily come from beyond context. Instead of sense perception and experience of particular things, al-Ghazāil argues for supernatural insight and prophecy. Instead of empirical demonstration, al-Ghazāil offers the distributed knowledge of the people. In the end, al-Ghazāli concludes that true and certain knowledge is not found with the philosopher but rather with the mystic.

While this disagreement involves important philosophical issues, I want to suggest that it also has significant implications beyond philosophical circles. al-Ghazā̄i acknowledged these implications and their significance, giving a number of reasons for why al-Farabi and Ibn Sina should be rejected as heretics. I want to focus on three issues, where the disagreement between these Islamic thinkers has implications far beyond the esoteric philosophical arguments being employed. In each case, the issues turn on the question of the importance of context, so 
that whether one takes context to have epistemological significance has considerable consequences that reach beyond the very small group of philosophers and their arguments.

\section{B. Historical Context}

\section{Al-Farabi}

Al-Farabi's book, The Book of Letters, is for the most part, a philosophical dictionary, listing Arabic words and how they are used in philosophical arguments. However, in the middle part of the book, alFarabi turns his attention to the origins of language and the relationship between these origins and the disciplines of philosophy and theology. For al-Farabi, philosophy and theology cannot be properly practiced unless their relationship to language is also understood. That is, for alFarabi, philosophy and theology are always practiced within the context of language, and more precisely, a specific language. To lose sight of this context, to ignore the fact that philosophers and theologians use words that belong to a particular language, is to invite confusion about the meaning of those words, and therefore introduce confusion into their philosophical and theological work.

It is significant that when al-Farabi begins his analysis of language, he does not begin with language itself but rather with a discussion of how people belong to a particular place.

The public and the multitude are the first to originate and come to be.

They come to be in a specific abode and country and have by nature specific forms and characters in their bodies. ${ }^{1}$

Every person has a natural place and culture which is their home and to which their character and bodies are accustomed. Why is this important? Well, for al-Farabi, when people first start to be curious about the world, when they first begin to think and value knowledge of the world, they start with what is closest to them and what is easiest to know. ${ }^{2}$ When thought and knowledge first appear, it is always a thinking and knowing about what is most accessible. In this way, knowledge of the

${ }^{1}$ al-Farabi, "The Book of Letters", Medieval Islamic Philosophical Writings, ed. M. Khalidi (Cambridge: Cambridge University Press, 2005), p. 4.

${ }^{2}$ Ibid., p. 5. 
world always begins as knowledge from a particular place and knowledge of a particular place.

Not surprisingly, this has implications for al-Farabi's account of the development of language. Adopting a classical account of language, al-Farabi takes the beginning of language to be the intent of one person wanting to communicate an idea to another person. ${ }^{3}$ For this purpose, people will use a sign for what is to be communicated. The sign people will use for communication will be a sign that imitates the thing and the sound used will be a sound that reflects the unique physiological qualities of that group of people. ${ }^{4}$ Initially, then, languages are dependent on the unique qualities of a place in that the signs will reflect the place's physical environment and the sounds will reflect the physiological makeup of the people living in that place.

Inevitably, languages will change. They will develop, becoming more eloquent and comprehensive. A few people will notice that there are similarities between signs and the mode of similarity will in turn be given a sign. ${ }^{5}$ In this way, a language develops the idea of universals. After these universals become part of the language, people will learn them and begin to study them. This in turn leads to the development of philosophy and religion. ${ }^{6}$ However, a different change comes when there is interaction between groups of people with different languages. In this case, there will be the transference of knowledge so that one group may adopt the religion or philosophy of another group. The question, then, for al-Farabi is whether the religion or philosophy should use the signs and expressions from the originating people or whether the receiving people should develop their own.

Here, we come up against the question of context. If a religious or philosophical idea or expression must be expressed using a particular language, then context is largely irrelevant. The meaning of those words and expressions are not limited to a particular place or people, but rather somehow transcends those contexts and takes on an ahistorical, acultural meaning. But as we have seen, for al-Farabi, language is always contextual. His advice, then, is that when religious or philosophical knowledge is

\footnotetext{
${ }^{3}$ Ibid., p. 5.

${ }^{4}$ Ibid., p. 5-6.

${ }^{5}$ Ibid., p. 15.

${ }^{6}$ Ibid., p. 18-19.
} 
transferred from one group of people to another, and it is possible, there should be a translation of terms. ${ }^{7}$ If there is a similarity between an expression in the first language and an expression in the second, people who use the second language should use the expression from their own language. If there is no similar expression in the second language, people who use the second language should adopt the expression from the first, but understand the expression as being one that belongs to all languages. For al-Farabi, then, it is crucial for the development of knowledge and understanding, that people not mix languages, since each language represents a particular and unique context.

Context is crucial for al-Farabi since all knowledge is dependent on the language in which it is expressed, and each language is in turn dependent on a particular group of people who use the language in a particular place. When it comes to adopting a new religion or philosophy, the adoption can only happen when people find some way of meaningfully translating the expressions of that religion or philosophy into the expressions already present in their own language. For al-Farabi, then, people, their languages and their knowledge, are always historically contingent, dependent on the unique particularities of place and physiology.

\section{Ibn Sina}

Like al-Farabi, Ibn Sina understands context as crucial for knowledge, but Ibn Sina, influenced by neo-Platonism, understands context primarily as the ground or source of knowledge. Context, then, is not so much the historical development of knowledge but rather more the possibility of knowledge.

According to Ibn Sina, the rational part of the human soul can be divided into a practical and theoretical faculty, both of which are called intellect. ${ }^{8}$ The practical intellect concerns itself with the body and the actions specific to it, such as desires, imagination and reflection. This practical intellect operates rationally, but also in accordance with social norms and values. Practical intellect acts according to principles of reason,

${ }^{7}$ Ibid., p. 25.

${ }^{8}$ Ibn Sina, "On the Soul", in M. Khalidi, Medieval Islamic Philosophical Writings, (Cambridge: Cambridge University Press, 2005), p. 27. 
but always within the context of the body. Practical intellect is at work when we reflect on what we want to do with our lives and how we will go about reaching our goals given the resources we have at hand and what is possible in the world we live in. For Ibn Sina, understanding context is crucial for the proper operation of the practical intellect since what is possible in our lives depends on what is possible in the world we live in.

What is possible for each of us, though, is limited by the unique particularities of our physical bodies. According to Ibn Sina, each human being has a unique soul that is specific to that particular body and essentially concerned with that body. ${ }^{9}$ The soul, then, is to a degree dependent on the body which it animates, insofar as each human soul is fitted for a particular human body but also requires the activity of that body for its proper operation. For Ibn Sina, though, this proper operation of the soul is not limited only to the practical intellect. Ibn Sina is not a dualist, separating the practical intellect from the theoretical. The soul is one and operates properly when the practical and theoretical intellects work together. The practical intellect, therefore serves a dual role. First, as described above, the practical intellect acts as the rational guide for daily life. However, the practical intellect also serves as the source of particulars from which the theoretical intellect abstracts universals and their meaning. ${ }^{10}$ Just as the practical intellect is dependent on a body for its operation, so also is the theoretical intellect dependent on the practical intellect. Pure theoretical intellect cannot function on its own but requires practical intellect to provide the material out of which meaning and universals are perceived. In this way, the theoretical intellect, via the practical intellect, is also dependent on the body for its proper operation, and therefore also dependent on context.

Ibn Sina lists four ways in which the soul is therefore dependent on the particulars given to it by practical intellect. ${ }^{11}$ First, our ability to know individual things is possible only through the experience and perception of particulars. From each particular, the soul abstracts universals which allow us to know that things are, and that there are similarities and differences. Second, the soul is able to recognize similarities of relations from the

\footnotetext{
9 Ibid., p. 44.

${ }^{10}$ Ibid., p. 45.

${ }^{11}$ Ibid.
} 
knowledge we have of particulars in order for us to have knowledge of relations between particulars. In this way, the soul is able to have knowledge, for example, of causality. Third, from particulars, the soul is able to form empirical judgments that give us knowledge of the nature of those particulars. According to Ibn Sina, the soul is therefore able to have knowledge, not only of how things are at some particular time, but rather how things are in their nature or essence. Perception allows us to observe how things are while reason leads us to the judgment that some qualities are not arbitrary but rather belong to the nature of the thing. Finally, the knowledge that comes from practical intellect is shared and agreed upon by groups of people assuring the theoretical intellect that this knowledge has been corroborated and is therefore reliable. Knowledge of particulars does not come solely from the individual but is also produced by groups of people who verify judgments regarding particulars. For Ibn Sina, then, knowledge is dependent on both individuals, with their particular bodily experience of things in the world, and larger particular groups of people who, together, work to ensure that this knowledge is certain.

While Ibn Sina's neo-Platonism leads him to conceive of knowledge in a far more abstract fashion than al-Farabi, nevertheless, like al-Farabi, Ibn Sina emphasizes the importance of context. For Ibn Sina, each human soul is unique and uniquely fitted for a particular body, ensuring that the rational activity of the soul is likewise uniquely fitted to that body. All of our knowledge is constrained by the particular characteristics of our bodies. Whatever we perceive, whatever we experience, is always the perception and experience characteristic of ourselves. Furthermore, what we perceive and experience of things is uniquely characteristic of those things. Just as each human being has a unique nature, so also do things in the world. In this way, no matter how abstract the knowledge, no matter how theoretical the reasoning, both require an empirical foundation built on sense perception and experience of things in the world. And to further ensure that this empirical foundation is solid and that our knowledge is certain, there must be the corroboration of other people. Ibn Sina's account of the fundamentally contextual nature of all knowledge and reasoning therefore leads to the conclusion that, as with al-Farabi, all people and their knowledge are historically contingent, dependent on the uniqueness of their bodies and the people they live with. 


\section{3. al-Ghazāta}

In his book, The Rescuer from Error, al-Ghazāil details his pursuit of a certainty that could withstand any doubt and survive even the authority of someone who could change stone into gold, or a stick into a snake. ${ }^{12}$ In a passage that bears a striking resemblance to Descartes' Meditations, al-Ghazāil describes how he began to examine his beliefs and finally came to the conclusion that they did not possess the certainty he felt was necessary for knowledge. Examining those beliefs that relied on sense perception, he concludes,

After a lengthy process of doubt, my mind did not allow me to maintain my trust in sensory beliefs either, and began gradually to cast doubt on them, saying: "Where does this confidence in sensory beliefs come from? ... [T] he judge of sensation makes its judgments, but the judge of reason then judges it to be false and disproves it irrefutably." ${ }^{\text {"13 }}$

According to al-Ghazāili, the senses cannot be the source of certain knowledge because the senses are frequently mistaken and need to be corrected by reason. It would seem, then, that reason might provide this foundation of certainty. But what of dreams? When one is dreaming, one believes that what is in the dream is real, and yet when we wake up we realize that it was not real. al-Ghazāil then asks, could it not be possible that what we are experiencing now is like a dream, and that we will soon wake up and realize that what reason tells us is true is only part of the dream and that there is a reality different from this dream? ${ }^{14}$ al-Ghazāil then searched for a solution to these doubts, but since any solution required a rational proof that started from a certainty, it became clear that no rational solution was possible.

But al-Ghazāi did not remain in this condition of doubt. As he describes it, God cured him and he was able to rid himself of his doubts and once again accept and trust what he had believed before. How did this happen? al-Ghazāin makes clear that the return of certainty was not the result of proofs or arguments, but rather "by a light that God Almighty cast into my breast, which is the key to the greater part of cognizance." ${ }^{15}$

${ }^{12}$ Al-Ghazā̄i, "The Rescuer from Error", in M. Khalidi (ed.), Medieval Islamic Philosophical Writings (Cambridge: Cambridge University Press, 2005), p. 61.

${ }^{13}$ Ibid., p. 62.

${ }^{14}$ Ibid.

${ }^{15}$ Ibid., p. 63. 
I don't want to speculate on the theological implications of this claim, but instead, I would like to focus on al-Ghazāli's claim that knowledge is dependent on this 'light'.

How then does al-Ghazāli understand the significance of this 'light'? First, it allows him to once again believe what he had believed before his journey of doubt. In other words, this 'light' did not lead to the rejection of what he had previously known, but instead allows him to embrace those beliefs with a renewed certainty. However, if this 'light' allows al-Ghazāil to take up what he had believed before, it does not allow him to return to the methods he had previously relied on to lead him to knowledge.

For first principles are not sought but are present, and if what is present is sought it will be lost and will disappear. ${ }^{16}$

Al-Ghazāli's experience of the 'light' leads him, then, to the conclusion that certain knowledge is not only possible but available, yet this knowledge is not available to any method of demonstration. Searching for certainty using methods of demonstration, whether these be empirical or rational, only leads to doubt and the loss of certainty. However, when one, like al-Ghazāli, abandons the methodical search for certainty, only then will the certainty already present in our knowledge be there for us. For al-Ghazāil, then, certain knowledge does not rely on proof but rather some quality that lies within the knowledge which is already available to us.

If al-Ghazāil rejects proof and demonstration as means of reaching knowledge, then what value is there in disciplines which rely on methods of proof, such as theology and philosophy? On this point, al-Ghazāil is ambiguous. In the case of theology, he acknowledges that there is a role for theology, namely preserving orthodox belief and arguing against heretics. ${ }^{17}$ Having said this, however, he then dismisses theology as mere conformity to tradition and "of little use for someone who only accepts necessary truths." ${ }^{18}$ Theology seems to be of value for most believers, in that it maintains the purity of the faith, but if one is seeking knowledge, then theology will be of no help. The case of philosophy is more
${ }^{16}$ Ibid., p. 64.
${ }^{17}$ Ibid., p. 65.
${ }^{18}$ Ibid. 
problematic. al-Ghazāil reserves his most vicious attacks for philosophy, which is filled with "ruses, deceptions, justifications, and illusions,"19 and philosophers, who are characterized as evil and malevolent. ${ }^{20}$ Yet, he also argues that some branches of philosophy, for example mathematics, contain important knowledge, leading to two forms of confusion. First, some people will be impressed with the clarity and rigor of mathematics and assume that the same clarity and rigor is characteristic of the other branches of philosophy, including those parts which deny religious belief. ${ }^{21}$ Second, some believers will mistakenly dismiss all of philosophy, including mathematics, because some philosophers deny religious belief. ${ }^{22}$ It seems, then, that for al-Ghazāil, philosophy contains some elements worth studying but that it is generally too dangerous for the general public. He concludes that access to philosophical works should be restricted to only the few who, one assumes, are enlightened enough to recognize the 'deceit and danger' of these works. ${ }^{23}$ It seems safe to say, then, that alGhazāTi does not see the intellectual pursuits as providing much benefit to humanity, and what benefit they do provide is limited to either the faithful transmission of tradition or the development of forms of knowledge, like mathematics, that have no relevance for religion.

The question is, then, if al-Ghazāir dismisses intellectual pursuits, from where does knowledge come? al-Ghazāli's answer is that there is a stage beyond the intellect whereby, in al-Ghazāli's words, another eye is opened and it is possible to "see supernatural things, the future and other matters from which the intellect is isolated." 24 The intellect, with its dependence on proofs and methods of demonstration, represents a lower level of perception and experience that sees those things which are intelligible. ${ }^{25}$ However, a higher level of perception and experience is found in prophecy, to use al-Ghazāli's term, which allows human beings to see the supernatural. As noted above, the knowledge given by prophecy is not the result of proofs and evidence, and so it is not appropriate to
${ }^{19}$ Ibid., p. 66.
${ }^{20}$ Ibid., p. 69.
${ }^{21}$ Ibid.
${ }^{22}$ Ibid., p. 70.
${ }^{23}$ Ibid., p. 75.
${ }^{24}$ Ibid., p. 83.
${ }^{25}$ Ibid., p. 84. 
ask for evidence. How then can one be certain about this knowledge? al-Ghazāi answers that we should look for the corroboration of a group of people, instead of individuals and particular proofs.

You will be like someone who has heard a report recurrently corroborated by a whole group of people. The certainty associated with the report cannot be said to derive from a single specific statement, but rather in an indefinite way. Although it does not derive from anyone outside the group, it cannot be traced back to any single individual. That is robust knowledge-based faith. ${ }^{26}$

Al-Ghazāil seems to be arguing that the most reliable source of knowledge comes from shared belief, insofar as the knowledge does not depend on anything particular but rather relies on the traditions of the group. Presumably, al-Ghazāil is arguing, in part, that knowledge which depends on a particular experience or argument could be mistaken, but it is far less likely that a group of people would be similarly mistaken. One person might be confused, but how likely is it that a group of people would share the identical confusion? In this way, al-Ghazāili argues against context as offering any possibility of certain knowledge. The lesser the role context plays in establishing the certainty of knowledge, the greater the likelihood of its certainty.

However, al-Ghazāil is not simply arguing that groups are more reliable than individuals. He gives the example of medicine as evidence of how this mystical knowledge operates. ${ }^{27}$ According to al-Ghazāil, people cannot understand how medicine is able to restore health, but nevertheless they do know that certain treatments of medications can cure certain illnesses. The restorative nature of medications cannot be uncovered by reason. Instead, we find this knowledge passed down by the tradition of doctors, which acknowledges that the medications work without giving proofs or explanations of discovery. According to al-Ghazāil, this knowledge:

cannot be apprehended by the people of intellect by dint of reason, but must be acquired by conforming to the tradition of the doctors, who in turn take it from the prophets, who ascertain the properties of things on

\footnotetext{
${ }^{26}$ Ibid., p. 86.

${ }^{27}$ Ibid., p. 87.
} 
account of a property of prophecy. ${ }^{28}$

It may be that groups are more reliable than individuals, but for al-Ghazāil, groups are also receptacles of mystical knowledge and the means, through tradition, for disseminating that knowledge to the general public and passing it on to the next generation. Groups of people, then, possess a shared knowledge, which originates in mystical insight, but has this origin erased and replaced by tradition. al-Ghazāil, then, denies context any role in relation to knowledge and certainty, going to the extreme of even denying significance to the context of mystical revelation. Knowledge may be the result of a mystical moment, but there is no importance given to the context of that moment. Since the source of knowledge is mystical, it matters not how we come to have our knowledge, only that we have it. If for al-Farabi and Ibn Sina it is the philosopher who represents the heights of knowledge, for al-Ghazāil it is the mystic, who has no name and no place.

For al-Ghazāil, his disagreements with al-Farabi and Ibn Sina were so great that he condemns al-Farabi and Ibn Sina as blasphemers ${ }^{29}$ and Muslim only in appearance ${ }^{30}$. I will leave aside their theological differences but instead focus on the implications of their philosophical disagreements and how this can be of use for us today. To do this, I will reflect on the implications both sides of this debate have on our understanding of global and local context, focusing on three issues: our ability to make a difference, the role of science in making a difference, and finally the role of reasoning in religion to cause believers to act differently. In this reflection, I will make no pretence of neutrality. I think there are good reasons for rejecting al-Ghazāli’s position and, if not agreeing, perhaps being more sympathetic to the arguments of al-Farabi and Ibn Sina. I won't present any arguments against al-Ghazāil, but rather try to show, on purely pragmatic grounds, why we ought to reject the claims of al-Ghazāil.

\section{History and Change}

Al-Farabì and al-Ghazāil represent two very different options for responding to local and global challenges. The choice between the two

\footnotetext{
${ }^{28}$ Ibid., p. 87.

${ }^{29}$ Ibid., p. 72.

${ }^{30}$ Ibid., p. 89.
} 
is a choice between making a change either by searching for something new or by turning back to habit. In al-Farabi, we are shown how language and knowledge change through a series of innovations that allow groups of people to both develop socially and increase their knowledge and understanding of the world. From the use of sounds to represent things, to the introduction of a written language, to the recognition of universal ideas, to the adoption of ideas from other groups of people, al-Farabi describes the ability of human beings to respond to local and global challenges as the ability to adapt and develop something new. In this way, local and global challenges are placed within a historical context that allows us to see our contemporary challenges as part of a long line of challenges that human beings have had some success in overcoming. Following al-Farabi, we can understand ourselves as part of a history of humanity that includes stories of innumerable challenges in a variety of contexts that human beings have overcome by doing something new or different, often in dramatic fashion.

This approach to local and global challenges represented by alFarabi stands in stark contrast to the approach represented by al-Ghazāil. For al-Ghazāil, there can be no history, no historical development of societies nor of knowledge, because all change is supernatural in origin, occurring outside of the natural order. On this account, societies and cultures do not change except when there is supernatural intervention through a prophetic word which is then deposited into the society or culture for safe keeping. This is an understanding of society and culture as being primarily passive, so that any change, good or bad, is seen as coming from an outside, supernatural source. On this account, local and global challenges are not understood as part of a history of challenges humanity has confronted and overcome, but rather as unique challenges imposed on this group of people or on humanity as a whole. An earthquake or the eruption of a volcano, then, is not part of a long history of natural disasters but rather a message from God. The dangers of globalization are not part of a history of increasing inter-dependence of countries and cultures, but rather a supernatural judgment on particular human practices. It follows, then, that if the local and global challenges we face are supernatural in origin, the response must address, not the natural context of those challenges, but rather their supernatural context. 
Furthermore, this response does not require any change beyond a return to what has already been revealed to a people. The appropriate response to the earthquake or financial crisis is already known, held as a shared wisdom, with its prophetic origins. A change is called for, but it is a change that leads people to return to what they already know and have had revealed to them. Following al-Ghazāil, then, we understand ourselves as part of a group that has within itself a shared knowledge which provides the appropriate context for any and all local and global challenges.

It seems to me though that there are a number of practical reasons why we should prefer a more historical approach, as seen in al-Farabi, to local and global challenges. While one might agree with al-Ghazāil that groups possess a shared wisdom or knowledge, most of the challenges facing us today require solutions that involve cooperation between groups. In these situations, individual groups cannot simply turn back to the way they have always done things, but must, instead, adapt to a new context that requires openness to the wisdom of other groups. As with al-Farabi's account of the development of language, which sees the adoption of ideas from other languages, so also must groups and societies try and find new ways of responding to the challenges they face by adopting what is good and true from other societies. Put differently, it is unlikely that groups and societies will be successful in responding to the challenges of today if they follow the way of thinking represented by al-Ghazāil and rely solely on their own knowledge and wisdom. Instead, the challenges of today require that groups and societies work together to find solutions to problems that cannot be solved alone.

It also seems to be the case that history itself has pushed aside the arguments of al-Ghazāil. The last few hundred years in the West have seen discoveries and achievements that would have been unimaginable for alGhazāri. We now have penicillin and insulin, computers and phones, the ability to travel to the moon and see to remote parts of the universe. What has made these possible is the very sort of method of demonstration that al-Ghazāil rejected, namely the scientific method. al-Ghazāil was correct that this kind of method of producing knowledge may not provide an absolute degree of certainty, but with the kinds of discoveries and developments that science has given the world, al-Ghazāli's argument 
may be irrelevant. The concrete and particular benefits of science seem far more real and significant for the world today than the esoteric doubts of al-Ghazāri. The sheer magnitude of the increase in knowledge in the West represents a very real and tangible obstacle to al-Ghazăli's argument that change is primarily the consequence of supernatural intervention. On the other hand, the kinds of changes experienced by people around the world due to the discoveries of science share a similarity to the account of the development of language we find in al-Farabi, with its accommodation and adoption of knowledge. In short, the events of the last few centuries can be seen as evidence that, at a pragmatic level, the more historical approach of al-Farabi, with its embrace of change and development, is more successful.

\section{Science}

From the above discussion of history, al-Ghazāil appears to be not only on the wrong side of history but also of science. Given al-Ghazāli's account of the development of the science of medicine, this should not be surprising. For al-Ghazāli, neither reason nor experience can provide medical knowledge. Instead, knowledge of medicine originates through supernatural intervention and is disseminated through the tradition of doctors. Doctors, then, only know that certain medications can be used for treating specific ailments, but they cannot know why they are effective. In part, this inability to know why medicine works lies in the fact that doctors are only working with knowledge that they have received from other sources, rather than from their own knowledge. However, I would like to suggest that, for al-Ghazāil, the kind of knowledge required to understand the workings of medicine is, in principle, not possible. According to al-Ghazāil, the world moves according to the will and command of God instead of according to the nature of things in the world. ${ }^{31}$ That is, things in the world do not have essential qualities but rather only have an appearance. The essence of a thing is not found in the thing but rather in God. The study of things in the world, will therefore only produce knowledge of appearances, which is why, for al-Ghazāil, any science that proceeds according to empirical study and demonstration, will fall short of being legitimate knowledge.

${ }^{31}$ Ibid., p. 71. 
This approach to science found in al-Ghazāli stands in contrast to that found in Ibn Sina. For Ibn Sina, the practical part of the soul is able to perceive the universal qualities of things and therefore understand the meaning of things. In addition, this practical intellect is able to perceive the empirical qualities of things so that there can be a degree of certainty that what is perceived by the soul as the idea of the thing is in fact the nature of the thing. In short, for Ibn Sina, every thing in the world has its own unique nature, and this nature is available to human intellect for understanding. Furthermore, for Ibn Sina, a science that proceeds according to empirical testing and verification is not only possible, but necessary for theoretical knowledge. Theoretical knowledge, with its reflection on God and the higher forms, requires a solid foundation built on practical knowledge. Or as Ibn Sina puts it, with the affairs of practical knowledge in their proper place, only then can theoretical intellect turn to the contemplation of God without distraction.

The choice between the approach of al-Farabi and Ibn Sina on one hand, and al-Ghazāi on the other, is then, not only a choice about the possibility and nature of change, but also the role of science in that change. For al-Ghazāil, the world has a regularity and order, but this order is found in God, not the world. Therefore, if one wants to respond to local or global challenges, one must ultimately turn ones attention to God. However, for Ibn Sina, the orderliness of the world comes from the nature of things. Therefore, if one wants to respond to local or global challenges, one can study how things are in the world in order to find appropriate solutions. This should not be taken as a rejection of God, since, for Ibn Sina, God is the First Cause. Rather, a scientific approach, with its emphasis on what is empirical and demonstrable, can provide solutions to challenges that are rooted in this world. Local challenges such as natural disasters and poverty, as well as global challenges like global warming, have their context within the natural world and therefore can find solutions in a scientific approach. And over the past few centuries, science has demonstrated many ways in which it can provide solutions to problems such as disease, natural disasters and poverty. It seems, then, that the approach of al-Farabi and Ibn Sina, with its openness to scientific knowledge, is the choice to be preferred, if for no other reason than science has proven to be remarkably successful in providing solutions to 
local and global challenges. However, it also seems more reasonable to think that the most effective solutions will be of the same nature as the problem. In this way, if we are looking for answers to local and global challenges that confront us in this world, we should look for answers that are likewise found in this world. For this reason, science must be an important part of responding to those challenges which are, to at least some degree, rooted in natural phenomena.

\section{E. Reason}

One might, then, summarize the difference between al-Farabi and Ibn Sina, on the one hand, and al-Ghazāil on the other, as a difference regarding the status of reason. In al-Farabi, we find a very high view of reason as people are able to overcome their differences and coordinate their actions in such a way as to achieve knowledge which is not limited to any specific group of people and allows for understanding of the workings of the world. Reason plays a significant role in developing relationships between people and allowing them to work together as represented in the development of language. Furthermore, not only does reason play a crucial role in the development of language, but it also has a universal quality that allows for groups of people to adopt ideas from other groups and languages. Reason allows individuals and groups to see what is common to all contexts and perceive what is universal and true in all cultures and languages. For al-Farabi, then, reason is necessary for the development of inter-personal relationships and knowledge of the world.

Ibn Sina has a similarly high view of reason. For Ibn Sina, reason has two important roles. The first role of reason, through the practical intellect, is to provide knowledge of the empirical world. This knowledge not only allows us to recognize that there is an order and structure to the world, but it also gives us access to universal truths found with the world. The second role of reason, through the theoretical intellect, is to then contemplate these truths as they relate to God and higher levels of understanding. Like al-Farabi, Ibn Sina sees reason as necessary for us to have any knowledge of the world as well that which is beyond this world.

This high view of reason stands in contrast to the much lower view found in al-Ghazāili. al-Ghazāili does not deny reason nor does he deny that reason can give us some kinds of knowledge, like mathematics 
for example. Instead, al-Ghazāil sees reason as providing only a limited knowledge of the world or understanding of how we should live in the world. As noted earlier, the knowledge found in the science of medicine is not, and cannot be, the result of reason but rather from supernatural sources. al-Ghazāil similarly dismisses the study of politics and ethics as only possessing knowledge that has been taken from religion. The following therefore represents the summary of al-Ghazâli's view of the limits of reason:

Whoever investigates these sciences will come to know with necessity that they can be apprehended only by means of divine inspiration and assistance from God Almighty, and that there is no way to acquire them by experience. ${ }^{32}$

Al-Ghazāi does not deny reason, but instead claims that when it comes to responding to local and global challenges, reason will be of no use. Whether these challenges are medical, political, ethical or natural, the only adequate response must be one that comes from supernatural sources.

The choice, then, between al-Farabī and Ibn Sina, and al-Ghazāil concerns the ability of human beings to reason together and find solutions to the challenges they face in the world today. For al-Farabi and Ibn Sina, people can work together to both understand the nature of these challenges and find solutions. The ability to talk and provide reasons to one another allows for people to work together and find the best solutions. The ability to use reason to discover what is true and real allows people to find solutions that are more likely to be effective and successful given the conditions we live in. On the other hand, for alGhazāil, there is no point in people working together to find solutions since human beings cannot discover answers by themselves. Instead, the best that people can do is return to how they have responded to challenges in the past and hope for supernatural intervention.

\section{F. Conclusion}

People disagree about the challenges, both local and global, that confront us today, debating the nature of these challenges as well as their relative significance. In part, these disagreements will revolve around the ${ }^{32}$ Ibid., p. 84. 
question of the contexts within which we understand the world around us. Do we understand global warming as a natural or moral phenomenon? Does the best response require us to return to the wisdom passed down through the ages or do we search for new solutions? Can we rely on reason to guide us or do we need something more? As I have tried to show above, the general forms these debates take are not unique to our time. In comparing al-Farabi and Ibn Sina on one side, and al-Ghazāii on the other, I want to argue that we can find guidance on responding to challenges today. I have also argued that given a choice between the two sides, we are better off siding with al-Farabi and Ibn Sina.

Following al-Farabi and Ibn Sina, we need to believe that we can change, adapt and find new solutions to the challenges that face us today. This is a pragmatic argument that brings together the practical observation that we need to first believe that we can change the world around us before we can find solutions to the problems in that world. In addition, the tremendous developments in the West over the last few centuries suggest that responding to challenges can bring about, not only change, but improvements in human life. Against al-Ghazāil, we should be open to the reality that, confronted with the challenges in our world today, we can find new ways of living our lives that not only overcome problems but also improve the conditions of our lives.

Following al-Farabi and Ibn Sina, we need to use science to help us better understand the world around us. Virtually all of the challenges that face us today are challenges that belong, to a greater or lesser degree, to the natural world. It therefore makes sense that we need to find solutions that are grounded in the natural world. And over the last few centuries, science has proven to be extraordinarily successful as a tool for finding solutions to problems in the natural world. Against al-Ghazāili, we should acknowledge that the scientific study of the natural world not only yields knowledge, but that it can be very useful in helping human beings respond to the challenges they face today.

Finally, following al-Farabi and Ibn Sina, we need to use reason to evaluate which solutions are the most appropriate and effective for the challenges facing us today. We cannot assume that there is only a single solution to every problem and so we need to be open to working together to find the best solutions. Whether it be evaluating various arguments or 
judging the effectiveness of different options, reason can be an effective tool for addressing the difficulties that human beings face today.

There may be many disagreements regarding the challenges that face us today, but we can be hopeful, knowing that human beings can respond to these challenges, using powerful tools such as science, and work together to find solutions that improve our lives, both locally and globally. 
Reflections on Context in Early Islamic Philosophy

\section{BIBLIOGRAPHY}

al-Farabi, "The Book of Letters", in M. Khalidi (ed.), Medieval Islamic Philosophical Writings, Cambridge: Cambridge University Press, 2005. al-GhazāII, "The Rescuer from Error", in M. Khalidi (ed.), Medieval Islamic Philosophical Writings, Cambridge: Cambridge University Press, 2005. Sina, Ibn, "On the Soul”, in M. Khalidi (ed.), Medieval Islamic Philosophical Writings, Cambridge: Cambridge University Press, 2005. 
Phil Enns 